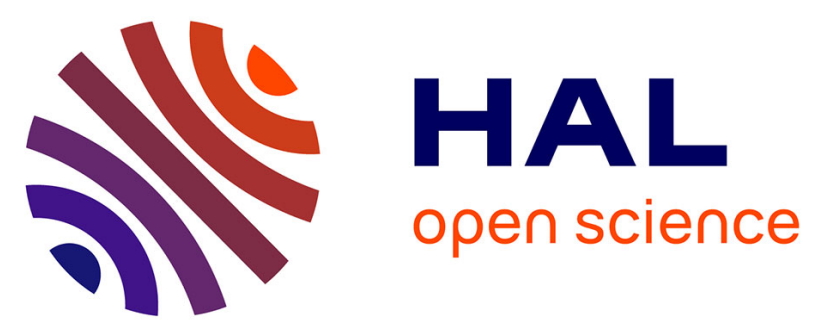

\title{
Solid-State Synthesis of Monazite-type Compounds Containing Tetravalent Elements
}

Damien Bregiroux, Olivier Terra, F. Audubert, Nicolas Dacheux, Virginie Serin, Renaud Podor, Didier Bernache-Assollant

\section{- To cite this version:}

Damien Bregiroux, Olivier Terra, F. Audubert, Nicolas Dacheux, Virginie Serin, et al.. Solid-State Synthesis of Monazite-type Compounds Containing Tetravalent Elements. Inorganic Chemistry, 2007, 46 (24), pp.10372-10382. 10.1021/ic7012123 . emse-00509266

\section{HAL Id: emse-00509266 \\ https://hal-emse.ccsd.cnrs.fr/emse-00509266}

Submitted on 19 Aug 2010

HAL is a multi-disciplinary open access archive for the deposit and dissemination of scientific research documents, whether they are published or not. The documents may come from teaching and research institutions in France or abroad, or from public or private research centers.
L'archive ouverte pluridisciplinaire $\mathbf{H A L}$, est destinée au dépôt et à la diffusion de documents scientifiques de niveau recherche, publiés ou non, émanant des établissements d'enseignement et de recherche français ou étrangers, des laboratoires publics ou privés. 


\section{Solid state synthesis of monazite-type compounds}

\section{containing tetravalent elements}

Damien Bregiroux ${ }^{a, b}$, Olivier Terra ${ }^{c}$, Fabienne Audubert ${ }^{a}$, Nicolas Dacheux ${ }^{c}$, Virgine Serin ${ }^{d}$, Renaud Podor $^{e}$ and Didier Bernache-Assollant ${ }^{f}$

a , Commissariat à l'Énergie Atomique, DEN/DEC/SPUA/LTEC, Cadarache, 13108 Saint Paul Lez Durance, France

b, Laboratoire Science des Procédés Céramiques et de Traitements de Surface, UMR-CNRS nº6638, 123 avenue Albert Thomas, 87060 Limoges, France

`, Institut de Physique Nucléaire d'Orsay, Groupe de Radiochimie, Université Paris-Sud-11, 91406 Orsay, France

d, Centre d'Elaboration de Matériaux et d'Etudes Structurales, Groupe Nanomatériaux, 29 rue Jeanne Marvig, BP 94347, 31055 Toulouse, France

e, Laboratoire de Chimie du Solide Minéral, UMR-CNRS 7555, Université Henri Poincaré Nancy 1, BP 239, 54506 Vandoeuvre lès Nancy, France

f, École Nationale Supérieure des Mines, CIS, 158 cours Fauriel, 42023 Saint Etienne, France

damien.bregiroux@ccr.jussieu.fr

* Corresponding author.

Present address: Université Pierre et Marie Curie - Paris 6, CNRS UMR 7574, Chimie de la Matière Condensée de Paris, 4, place Jussieu, Paris F-75005, France. Tel.: +33 144274770, Fax: +33 144272548 


\section{Introduction}

In the framework of the French research law related to the specific conditioning of long life radionuclides in dedicated ceramics, phosphate matrices were extensively studied. ${ }^{15}$ On the basis of several properties of interest such as weight loading, ${ }^{6}$ sintering capability, ${ }^{7,8}$ resistance to aqueous alteration $^{811}$ or to radiation damage, ${ }^{12,16}$ monazites $\left(\mathrm{M}^{\mathrm{III}} \mathrm{PO}_{4}\right)$, brabantites $\left(\mathrm{M}_{0.5}^{\mathrm{II}} \mathrm{M}^{\mathrm{IV}}{ }_{0.5} \mathrm{PO}_{4}\right)$ and associated monazite/brabantite solid solutions $\left(\mathrm{M}^{\mathrm{III}}{ }_{1-2 x} \mathrm{M}^{\mathrm{II}}{ }_{x} \mathrm{M}^{\mathrm{IV}}{ }_{x} \mathrm{PO}_{4}\right)$ were selected to perform advanced kinds of experiments through, as instance, the French Research Group NOMADE (CNRS/CEA/AREVA/EDF/French universities) in the field of the so called "Technical Feasability". ${ }^{17}$ The synthesis of monazites, especially pointing out the preparation ${ }^{1,18}$, the process $^{2124}$ or the optimization of specific properties required ${ }^{9,16}$ was already described. On the basis of their redox properties, the actinides considered for the development of such matrices, could be mainly trivalent $(\mathrm{Pu}$, $\mathrm{Am}, \mathrm{Cm})$ or tetravalent $(\mathrm{Th}, \mathrm{U}, \mathrm{Np}, \mathrm{Pu})$ which strengthens the interest of designing matrices which could accept both tri- and tetravalent elements in their structure, e.g. $\mathrm{M}^{\mathrm{III}}{ }_{1-2 x} \mathrm{M}^{\mathrm{II}}{ }_{x} \mathrm{M}^{\mathrm{IV}}{ }_{x} \mathrm{PO}_{4} \cdot{ }^{5,7}$

From a geochemical point of view, monazite $\left(\mathrm{LnPO}_{4}\right.$ with $\mathrm{Ln}$ : $\left.\mathrm{La}-\mathrm{Tb}\right)$ is the most abundant lanthanide phosphate observed in natural samples. ${ }^{25}$ Such minerals appear as the major thorium source on earth, especially in several ores which contain up to 14.3 wt. $\%$ and 15.6 wt. $\%$ in $\mathrm{ThO}_{2}$ and $\mathrm{UO}_{2}$,

respectively. ${ }^{26,27}$ Some other observations revealed the presence of samples containing up to $50 \mathrm{wt} . \%$ of thorium and consequently no indication of the presence of lanthanides in the minerals. ${ }^{25,28,29}$ The incorporation of both tetravalent elements in the monazite structure was usually explained by the two following coupled substitutions:

$$
\begin{aligned}
& 2 \mathrm{Ln}^{3+} \Leftrightarrow(\mathrm{Th}, \mathrm{U})^{4+}+\mathrm{Ca}^{2+} \\
& \mathrm{Ln}^{3+}+\mathrm{PO}_{4}{ }^{3-} \Leftrightarrow(\mathrm{Th}, \mathrm{U})^{4+}+\mathrm{SiO}_{4}{ }^{4-}
\end{aligned}
$$

Some analyses carried out on natural samples revealed that the mechanism described by (eq 1) is widely predominant. ${ }^{3032}$ It leads to a complete and ideal solid solution $\mathrm{M}^{\mathrm{III}}{ }_{1-2 x} \mathrm{M}^{\mathrm{II}}{ }_{x} \mathrm{M}^{\mathrm{IV}}{ }_{x} \mathrm{PO}_{4}$, between pure monazite and pure brabantite $\left(\mathrm{M}_{0.5}^{\mathrm{II}} \mathrm{M}^{\mathrm{IV}}{ }_{0.5} \mathrm{PO}_{4}\right){ }^{33}$ Van Emden et al. also noted that in several samples containing cerium, the $(\mathrm{Ca}+\mathrm{Si})$ content was higher than $(\mathrm{Th}+\mathrm{U})^{32}$ leading to the conclusion that 
tetravalent cerium was probably incorporated in the monazite structure through both coupled substitutions. However, no analysis was carried out to validate this hypothesis. In the field of the second coupled substitution (eq 2), one of the $\mathrm{ThSiO}_{4}$ form is isostructural from $\mathrm{LaPO}_{4}$ (monoclinic system, S.G.: $\mathrm{P} 2{ }_{1} / \mathrm{n}$ ) which is not the case for $\mathrm{USiO}_{4}$ (tetragonal system, S.G.: $\mathrm{I}_{1} /$ amd). It is worth noting that $\mathrm{ThSiO}_{4}$ could exist in both crystallographic forms; ${ }^{34}$ the phase transition from tetragonal to monoclinic occurring at about $1200^{\circ} \mathrm{C}$. Moreover, $\mathrm{USiO}_{4}$ is unstable at temperatures higher than $500^{\circ} \mathrm{C}$ in air $(1$ atm.) and decomposes into $\mathrm{UO}_{2}$ and $\mathrm{SiO}_{2}{ }^{35 ; 36}$

The preparation of synthetic actinide bearing monazites was driven either by wet or dry chemistry methods. Among the methods based on wet chemistry processes, a large part involved the precipitation of initial crystallized precursors (e.g. rhabdophanes of formula $\mathrm{LnPO}_{4} \cdot 1 / 2 \mathrm{H}_{2} \mathrm{O}$ ) 37 then an heating treatment above $700^{\circ} \mathrm{C}$.

For trivalent actinides, these methods allowed the preparation of $\mathrm{AnPO}_{4}$ (with $\mathrm{An}=\mathrm{U}, \mathrm{Pu}, \mathrm{Am}-\mathrm{Bk}$ ). The incorporation of trivalent uranium, which appears rather curious from a redox point of view, was obtained in anoxic conditions and in presence of formic acid from a mixture of $\mathrm{Na}_{3} \mathrm{PO}_{4}$ and trivalent uranium solution. ${ }^{38}$ The preparation of $\mathrm{PuPO}_{4}$ was reported from $\mathrm{PuPO}_{4} \cdot 1 / 2 \mathrm{H}_{2} \mathrm{O}$ precipitated between $75^{\circ} \mathrm{C}$ and $90^{\circ} \mathrm{C}$ from a mixture of trivalent plutonium and phosphoric acid in presence of concentrated sulphuric acid or from a mixture of plutonium trichloride and $\left(\mathrm{NH}_{4}\right)_{2} \mathrm{HPO}_{4} \cdot{ }^{39,40}$ After heating above $950^{\circ} \mathrm{C}$, this blue well crystallized precursor was fully transformed into Pu-monazite. ${ }^{40,41}$ More recently, the preparation of $\mathrm{La}_{1-x} \mathrm{Am}_{x} \mathrm{PO}_{4}$ with large amounts of ${ }^{241} \mathrm{Am}$ was reported by Aloy et al. ${ }^{42}$ from associated precipitated rhabdophanes. The same way was finally applied to prepare Am-monazite samples from Am-rhabdophane ${ }^{43,44}$ at the gram scale and $\mathrm{CmPO}_{4},{ }^{45,46} \mathrm{BkPO}_{4}, \mathrm{CfPO}_{4}$ and EsPO 4 at the microgram scale. ${ }^{46}$ The main conclusion is that, excepted for U-monazite which preparation remains doubtful due to the low stability of trivalent oxidation state of uranium, An-monazite samples can be obtained easily from plutonium to einsteinium by using wet chemistry methods.

On the contrary, some other actinides $(\mathrm{Th}, \mathrm{Pa}, \mathrm{Np})$ can not be incorporated in their trivalent oxidation state in the monazite structure that requires their incorporation by the way of coupled substitution, as 
described in (eq 1) and (eq 2). Moreover, brabantites and monazite/brabantite solid solutions are rather difficult to obtain through wet chemistry methods. In this field, Podor et al. synthesized several single crystals of $\mathrm{La}_{1-2 x} \mathrm{Ca}_{x} \mathrm{An}_{x} \mathrm{PO}_{4}$ solid solutions (with $\mathrm{An}(\mathrm{IV})=\mathrm{Th}$, $\mathrm{U}$ ) by putting mixtures of $\mathrm{La}(\mathrm{OH})_{3}$, $\mathrm{Ca}(\mathrm{OH})_{2}$ or $\mathrm{CaO}$ and $\mathrm{An}(\mathrm{OH})_{4}$ or $\mathrm{AnO}_{2}$ with concentrated phosphoric acid in hydrothermal conditions near to geological conditions $\left(\mathrm{t}=24\right.$ hours, $T=780^{\circ} \mathrm{C}, \mathrm{P}=200 \mathrm{MPa}, \mathrm{Ni} / \mathrm{NiO}$ buffer to control the dioxygen fugacity and to avoid the oxidation of uranium (IV) into uranyl). ${ }^{47,48}$ By this way, polyphase systems composed by $\mathrm{Ca}_{0.5} \mathrm{U}_{0.5} \mathrm{PO}_{4}$ and $\mathrm{U}_{2}\left(\mathrm{PO}_{4}\right)\left(\mathrm{P}_{3} \mathrm{O}_{10}\right)^{49}$ were always prepared, leading to the same conclusions than that given by Muto et al..$^{50}$

According to literature, single crystals of monazite and monazite/brabantite solid solutions were usually prepared by the flux method from a mixture of rare-earth oxide and lead diphosphate at $1300^{\circ} \mathrm{C} .{ }^{51}$ The crystals of monazite (or monazite/brabantite), formed during the cooling step $\left(975^{\circ} \mathrm{C} \leq T\right.$ $\leq 1300^{\circ} \mathrm{C}$ ) were finally isolated by preferential dissolution of $\mathrm{PbP}_{2} \mathrm{O}_{7}$ in hot concentrated nitric acid. $\mathrm{By}$ the way, several authors reported the formation of samples doped with uranium (up to $10 \mathrm{wt} . \%$ ), neptunium (3.0 wt.\%), plutonium (6.0 wt.\%), americium (up to $0.5 \mathrm{wt} . \%$ ) or curium $(0.1 \mathrm{wt} . \%) ., 62,53$ While the formation of Am- or $\mathrm{Cm}$-doped monazite samples is not surprising taking into account the stabilization of the trivalent oxidation state of these actinides, the incorporation of the two tetravalent actinides $(\mathrm{U}, \mathrm{Np})$ in monazite samples could not be explained by the formation of vacancies for the weight loadings considered but probably involves the formation of $\operatorname{Ln}_{1-2 x} \mathrm{~Pb}_{x} \mathrm{An}_{x} \mathrm{PO}_{4}$ solid solutions as an explanation of such weight loadings with tetravalent actinides. ${ }^{54}$ For $\mathrm{Pu}$-doped samples, the stabilization of both oxidation states could be also evoked ${ }^{39,40,55}$ even though the probability of the presence of $\mathrm{Pu}(\mathrm{III})$ appears to be more important on the basis of the reduction of $\mathrm{Pu}(\mathrm{IV})$ into $\mathrm{Pu}(\mathrm{III})$, as already discussed in literature..$^{56,57}$

Consequently, the incorporation of high weight loadings of tetravalent actinides in the monazite structure requires one of the two coupled substitutions discussed in (eq 1) and (eq 2). This incorporation, which appears difficult to reach by wet chemistry methods, seems to occur only considering dry chemistry methods. Indeed, samples of $\mathrm{Ca}_{0.5} \mathrm{An}_{0.5} \mathrm{PO}_{4}(\mathrm{An}=\mathrm{Th}, \mathrm{U}$ or $\mathrm{Np})$ were 
prepared as single phase after heating a mixture of $\mathrm{AnO}_{2}, \mathrm{CaCO}_{3}$ and $\left(\mathrm{NH}_{4}\right)_{2} \mathrm{HPO}_{4}$ at high temperature under inert conditions. ${ }^{58,59}$ Tabuteau et al. reported the formation of $\mathrm{Ca}_{0.5} \mathrm{~Np}_{0.35} \mathrm{Pu}_{0.15} \mathrm{PO}_{4}$ through the simultaneous incorporation of tetravalent neptunium and plutonium. ${ }^{59}$ According to some recent experiments, samples of $\mathrm{Pu}_{0.4}^{\mathrm{III}} \mathrm{Pu}^{\mathrm{IV}}{ }_{0.3} \mathrm{Ca}_{0.3} \mathrm{PO}_{4}$ monazite/brabantite solid solution were also obtained at high temperature. ${ }^{16}$ On the contrary, the application of the same procedure to the preparation of $\mathrm{Ca}_{0.5} \mathrm{Pu}_{0.5} \mathrm{PO}_{4}$ remained unsuccessful, probably due to the reduction of $\mathrm{Pu}(\mathrm{IV})$ into $\mathrm{Pu}(\mathrm{III})$ during the heating treatment, leading to the formation of $\mathrm{PuPO}_{4} \cdot{ }^{59}$ The same conclusion was given on the basis of several attempts to stabilize tetravalent cerium as $\mathrm{Ca}_{0.5} \mathrm{Ce}_{0.5} \mathrm{PO}_{4}$. Heindl et al. used the high temperature solid state route to synthesize $\mathrm{M}_{0.5}^{\mathrm{II}} \mathrm{Ce}^{\mathrm{IV}}{ }_{0.5} \mathrm{PO}_{4}$ (with $\mathrm{M}^{\mathrm{II}}=\mathrm{Ca}, \mathrm{Ba}$ and $\mathrm{Sr}$ ). ${ }^{60}$ All the resulting powders were green colored. Moreover, the XRD lines exhibited a shift towards the small $2 \theta$ angles compared to the diagram of $\mathrm{CePO}_{4}$ which is not in agreement with the fact the $1 / 2\left(\mathrm{Ce}^{\mathrm{IV}}+\mathrm{Ca}^{\mathrm{II}}\right)$ couple is smaller than $\mathrm{Ce}^{\mathrm{III}}$. More recently, Pepin et al. performed the same experiment but observed neither green color, nor shift in the XRD lines. They also noted the presence of a secondary phase, $\mathrm{Ca}_{2} \mathrm{P}_{2} \mathrm{O}_{7}{ }^{61}$ The relationship between the $\mathrm{Ca}$ content and the powder color of $(\mathrm{Ce}, \mathrm{Ca}) \mathrm{PO}_{4}$ was recently used by Imanaka et al. and Sivakumar et al. for the elaboration of green pigments. ${ }^{62 ; 63}$ Nevertheless, the authors did not determine the valence state of cerium in these powdered samples.

On the basis of such results, Podor et al. described the limit of incorporation of tetravalent element in brabantite samples, $\mathrm{M}_{0.5}^{\mathrm{II}} \mathrm{M}^{\mathrm{IV}}{ }_{0.5} \mathrm{PO}_{4}$, versus the ionic radius of divalent cation, $\overline{\mathrm{IX}_{\mathrm{r}\left(\mathrm{M}^{\mathrm{II}}\right)}}$, tetravalent cation, $\overline{\mathrm{IX}_{\mathrm{r}\left(\mathrm{M}^{\mathrm{IV}}\right)}}$ and the average cationic radius $\overline{\mathrm{IX}_{\mathrm{r}\left(\mathrm{M}^{\mathrm{IV}+\mathrm{II}}\right)}}$ in the nine-fold coordination through the two following relationships: ${ }^{47 ; 48}$

$$
\begin{aligned}
& 1.107 \AA \leq \overline{I X_{r}\left(\mathrm{M}^{\mathrm{IV}+\mathrm{II}}\right)} \leq 1.216 \AA \\
& 1.082 \leq \overline{I X_{r\left(\mathrm{M}^{\mathrm{II}}\right)}} / \overline{I X_{r}\left(\mathrm{M}^{\mathrm{IV}}\right)} \leq 1.238
\end{aligned}
$$

which becomes:

$$
\begin{aligned}
& 1.107 \AA \leq \overline{I X_{r}\left(\mathrm{M}^{\mathrm{III}+\mathrm{IV}+\mathrm{II}}\right)} \leq 1.216 \AA \\
& 1 \leq \overline{I X_{r}\left(\mathrm{M}^{\mathrm{III}+\mathrm{II}}\right)} / \overline{I X_{r}\left(\mathrm{M}^{\mathrm{III}+\mathrm{IV}}\right)} \leq 1.238
\end{aligned}
$$


with

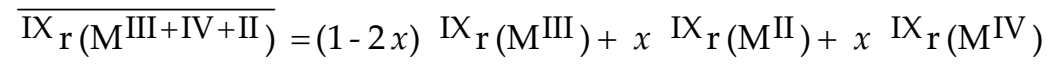

and

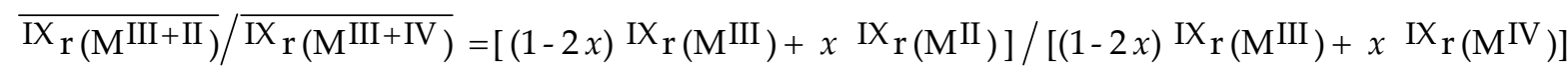

when discussing about the simultaneous substitution of trivalent lanthanide by divalent and tetravalent cations in monazite/brabantite solid solutions, $\mathrm{M}^{\mathrm{III}}{ }_{1-2 x} \mathrm{M}_{x}^{\mathrm{II}} \mathrm{M}^{\mathrm{IV}}{ }_{x} \mathrm{PO}_{4}$.

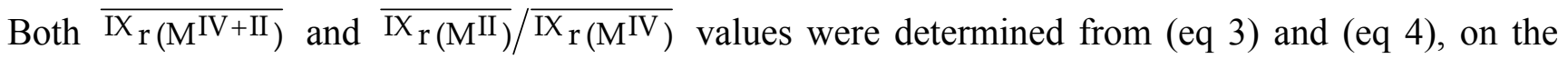
one hand, and from the ionic radii of actinides determined according to Shannon ${ }^{64}$ with the assumption that the evolution of the actinide ionic size follows a linear function of the atomic number as well as in the eightfold coordination, ${ }^{16}$ on the other hand. These values reach $1.105 \AA$ and $1.14,1.10 \AA$ and 1.16 and $1.09 \AA$ and 1.17 for $\mathrm{Ca}_{0.5} \mathrm{~Np}_{0.5} \mathrm{PO}_{4}, \mathrm{Ca}_{0.5} \mathrm{Ce}_{0.5} \mathrm{PO}_{4}$ and $\mathrm{Ca}_{0.5} \mathrm{Pu}_{0.5} \mathrm{PO}_{4}$, respectively. Based on these results, the formation of $\mathrm{Ca}_{0.5} \mathrm{Pu}_{0.5} \mathrm{PO}_{4}$ and $\mathrm{Ca}_{0.5} \mathrm{Ce}_{0.5} \mathrm{PO}_{4}$ brabantites would be difficult since the $\overline{\mathrm{IX}_{\mathrm{r}\left(\mathrm{M}^{\mathrm{IV}+\mathrm{II}}\right)}}$ value does not satisfy the inequality given in (eq 3) while that of $\mathrm{Ca}_{0.5} \mathrm{~Np}_{0.5} \mathrm{PO}_{4}$ and $\mathrm{Ca}_{0.5} \mathrm{~Np}_{0.35} \mathrm{Pu}_{0.15} \mathrm{PO}_{4}$ remains possible, as described in literature. In the same way, the maximum incorporation of tetravalent actinide/element in $\mathrm{M}^{\mathrm{III}}{ }_{1-2 x} \mathrm{M}_{x}^{\mathrm{II}} \mathrm{M}^{\mathrm{IV}}{ }_{x} \mathrm{PO}_{4}$ was evaluated for $\mathrm{M}^{\mathrm{III}}=\mathrm{La}$ and $\mathrm{M}^{\mathrm{II}}$ $=\mathrm{Ca}$. The results are reported in Table 1 . One can note that the coupled substitution $2 \mathrm{Ln}^{\mathrm{III}} \Leftrightarrow \mathrm{M}^{\mathrm{IV}}+\mathrm{M}^{\mathrm{II}}$ would not be complete for cerium $\left(x_{\max }=0.47\right)$ or plutonium $\left(x_{\max }=0.45\right)$.

Table 1. Ionic radii of some tetravalent actinides in the ninefold coordination and their maximum incorporation in $\mathrm{LaPO}_{4}\left(\mathrm{La}_{1-2 \mathrm{x}} \mathrm{M}^{\mathrm{IV}}{ }_{\mathrm{x}} \mathrm{Ca}_{\mathrm{x}} \mathrm{PO}_{4}\right)$

\begin{tabular}{cccccc}
\hline $\mathbf{M}^{\mathrm{IV}}$ & $\mathbf{C e}$ & $\mathbf{T h}$ & $\mathbf{U}$ & $\mathbf{N p}$ & $\mathbf{P u}$ \\
\hline$\overline{\mathrm{IX}_{\mathrm{r}_{\mathrm{M}(\mathrm{IV})}}}$ & $1.02 \AA$ & $1.09 \AA$ & $1.05 \AA$ & $1.03 \AA$ & $1.01 \AA$ \\
\hline$x_{\max .}$ & 0.47 & 0.50 & 0.50 & 0.49 & 0.45 \\
\hline
\end{tabular}

The aim of this paper is thus to investigate (reexamine) the incorporation of three tetravalent elements (Th, U, Ce) in the brabantite structure through high temperature solid state route. In this work, thorium is considered on the basis of its stabilized tetravalent oxidation state which excludes other redox 
reactions. On the contrary, tetravalent uranium that can be oxidized and cerium (used as a plutonium surrogate) that can be reduced have been considered in a second part of the work. A particular aspect of this study consists in the description of the schematic scheme of incorporation of these three tetravalent elements (Th, U, Ce) in the brabantite structure, as a preliminary work dedicated to the formation of monazite/brabantite solid solutions including tetravalent thorium and/or uranium.

\section{Experimental section}

All the samples were prepared by firing initial mixtures containing $\mathrm{MO}_{2}, \mathrm{Ca}\left(\mathrm{HPO}_{4}\right) \cdot 2 \mathrm{H}_{2} \mathrm{O}$ (or $\mathrm{CaO}$ for cerium compounds) and $\mathrm{NH}_{4} \mathrm{H}_{2} \mathrm{PO}_{4} \cdot{ }^{1,17}$ In order to increase the reactivity of the initial mixtures, the starting materials were ground for few minutes by mechanical grinding in zirconia bowls before being fired under inert atmosphere $(\mathrm{M}=\mathrm{U}$ and $\mathrm{Th})$ or in air $(\mathrm{M}=\mathrm{Ce})$ in alumina boats with heating and cooling rates of $10^{\circ} \mathrm{C} \cdot \mathrm{min}^{-1}$. In the field of the improvement of the final homogeneity of the samples, the optimization of the grinding conditions was already described for several phosphate ceramics doped with thorium and/or uranium such as thorium phosphate-diphosphate solid solutions, britholites, monazites and monazite/brabantite solid solutions. ${ }^{7}$

The thermal behaviour of the mixtures was followed by differential thermal analysis (DTA) and thermogravimetry (TG) using a Setaram TG 92-16 apparatus in platinum crucibles. All the XRD analyses were performed on powdered samples at room temperature using a Bruker D8 Advance X-ray diffractometer $\left(\mathrm{Cu} \mathrm{K}_{\alpha}=0.15418 \mathrm{~nm}\right)$. The unit cell parameters were refined using U-Fit or PowderCell software. $^{65,66}$

The Electron Probe MicroAnalyses (EPMA) experiments were carried out using Cameca SX 50 and SX 100 apparatus (operating with an acceleration voltage of $15 \mathrm{kV}$ and a current intensity of $10 \mathrm{nA}$ ). The calibration standards used were mainly $\mathrm{LaPO}_{4}$ and $\mathrm{CePO}_{4}$ monazites $\left(\mathrm{K}_{\alpha}\right.$ emission of phosphorus and $\mathrm{L}_{\alpha}$ emission of cerium, respectively), wollastonite $\mathrm{Ca}_{2} \mathrm{SiO}_{4}\left(\mathrm{~K}_{\alpha}\right.$ emission of calcium), $\mathrm{ThO}_{2}\left(\mathrm{M}_{\alpha}\right.$ emission of thorium) and $\mathrm{UO}_{2.12}\left(\mathrm{M}_{\beta}\right.$ emission of uranium). It is worth noting that some interferences were detected during the EPMA analyses in the samples containing simultaneously large amounts of 
calcium and uranium, leading to the systematic over-estimation of the calcium content, as already discussed for $\mathrm{Ca}_{9} \mathrm{Nd}_{0.5} \mathrm{U}_{0.5}\left(\mathrm{PO}_{4}\right)_{4.5}\left(\mathrm{SiO}_{4}\right)_{1.5} \mathrm{~F}_{2}$ (U-britholites) samples. ${ }^{3}$

$\mu$-Raman spectra were recorded with a microspectrometer LABRAM (Dilor - Jobin Yvon) using an argon laser operating at $514.5 \mathrm{~nm}$ with a power in the range 1-10 $\mathrm{mW}$. The sample position was checked thanks to an Olympus microscope.

Transmission electron microscopy (TEM) and Electron Energy Loss Spectroscopy (EELS) analyses were performed in the SACTEM-Toulouse, using a Tecnai F20 (FEI) equipped with an objective lens aberration corrector (CEOS) and imaging filter (Gatan Tridiem).

\section{Results and discussion}

\subsection{Preparation of $\mathrm{Ca}_{0.5} \mathrm{Th}_{0.5} \mathrm{PO}_{4}$}

The synthesis of $\mathrm{Ca}_{0.5} \mathrm{Th}_{0.5} \mathrm{PO}_{4}$ was followed, from a starting mixture of $\mathrm{Ca}\left(\mathrm{HPO}_{4}\right) \cdot 2 \mathrm{H}_{2} \mathrm{O}$, $\mathrm{ThO}_{2}$ and $\mathrm{NH}_{4} \mathrm{H}_{2} \mathrm{PO}_{4}$, versus the heating temperature $\left(400 \leq T \leq 1400^{\circ} \mathrm{C}\right)$ using DTA/TG experiments (Figure 1). 

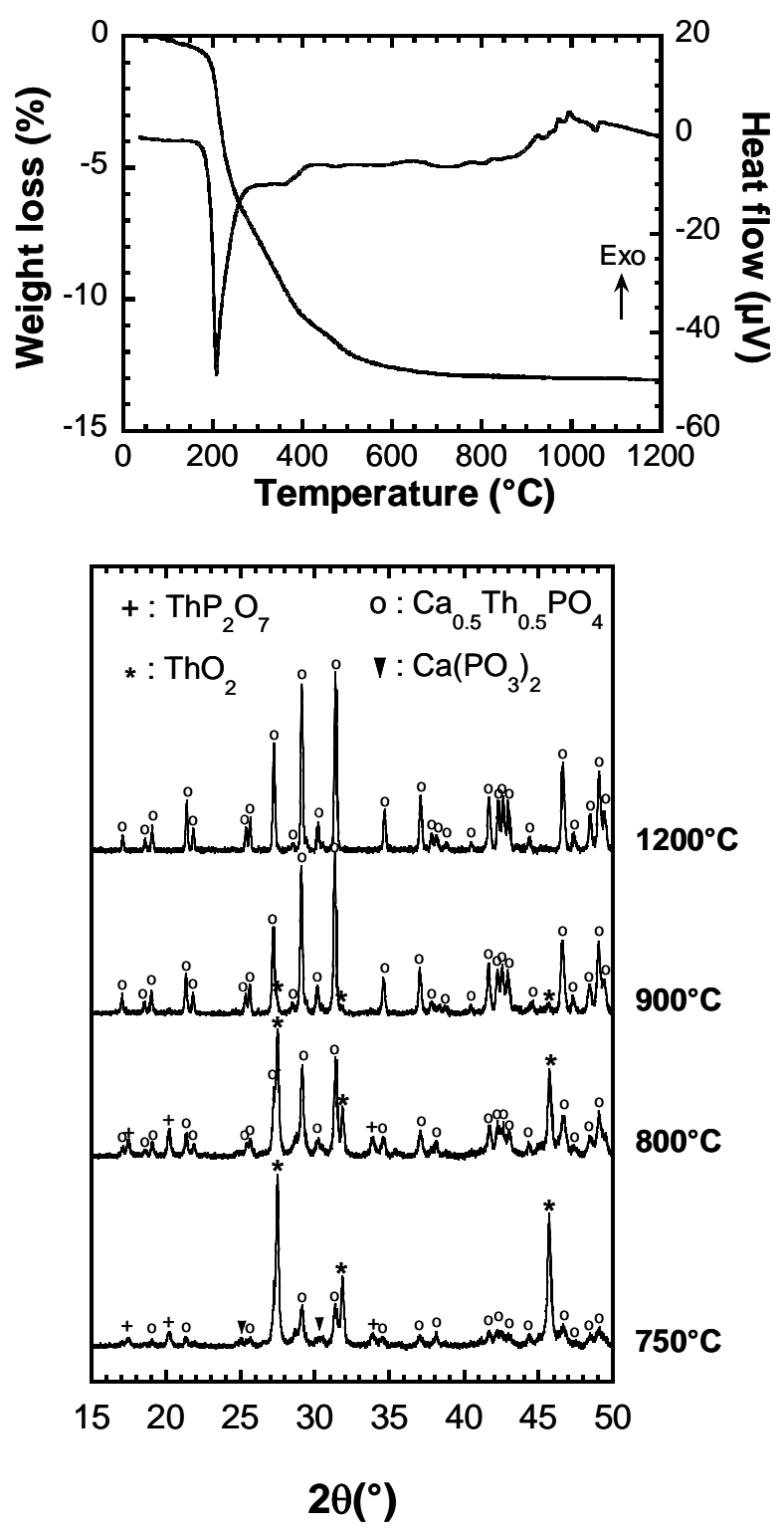

Figure 1. Thermal analysis under argon and X-ray diffraction analysis of a $\mathrm{ThO}_{2}-\mathrm{Ca}\left(\mathrm{HPO}_{4}\right) \cdot 2 \mathrm{H}_{2} \mathrm{O}-$ $\mathrm{NH}_{4} \mathrm{H}_{2} \mathrm{PO}_{4}$ mixture.

The total weight loss observed on the TG curves (i.e. $\approx 13 \%$ ) occurs in several steps below $600^{\circ} \mathrm{C}$. It was associated with the dehydration of $\mathrm{Ca}\left(\mathrm{HPO}_{4}\right) \cdot 2 \mathrm{H}_{2} \mathrm{O}$ and to the decomposition of $\mathrm{NH}_{4} \mathrm{H}_{2} \mathrm{PO}_{4}$. Between $180^{\circ} \mathrm{C}$ and $400^{\circ} \mathrm{C}$, the total weight loss $(\approx 10.8 \%)$ was associated with three endothermic effects located at $208^{\circ} \mathrm{C}, 360^{\circ} \mathrm{C}$ and $474^{\circ} \mathrm{C}$, assigned to the release of water, to the condensation of hydrogenphosphate groups into polytrioxophosphate entities and finally to the quantitative release of $\mathrm{NH}_{3}{ }^{67}$ No additional weight loss is observed above $600^{\circ} \mathrm{C}$ while several exothermic effects are 
observed at $777^{\circ} \mathrm{C}, 827^{\circ} \mathrm{C}, 925^{\circ} \mathrm{C}, 970^{\circ} \mathrm{C}$ and $994^{\circ} \mathrm{C}$, due to reactions occurring between several intermediates as discussed thereafter. Some of these peaks were globally associated to the formation then decomposition of thorium diphosphate $\left(\alpha-\mathrm{ThP}_{2} \mathrm{O}_{7}\right)$, calcium polytrioxophosphate $\left(\mathrm{Ca}\left(\mathrm{PO}_{3}\right)_{2}\right)$ and to the formation of $\mathrm{Th}$-brabantite (i.e. $\mathrm{Ca}_{0.5} \mathrm{Th}_{0.5} \mathrm{PO}_{4}$ ).

The chemical reactions occurring during the formation of Th-brabantite was also followed versus the heating temperature through XRD on samples heated at several temperatures ranging from 400 to $1400^{\circ} \mathrm{C}$ (Figure 1). Between 400 and $700^{\circ} \mathrm{C}$, the $\mathrm{XRD}$ patterns always reveal the presence of $\mathrm{ThO}_{2}$ [JCPDS File \# 42-1462] while the XRD lines of $\mathrm{Ca}\left(\mathrm{HPO}_{4}\right) \cdot 2 \mathrm{H}_{2} \mathrm{O}$ and $\mathrm{NH}_{4} \mathrm{H}_{2} \mathrm{PO}_{4}$ progressively disappear for the benefit of that of $\mathrm{Ca}\left(\mathrm{PO}_{3}\right)_{2}$ [JCPDS File \# 9-363] formed as an intermediate product. Above $750^{\circ} \mathrm{C}$, all the XRD lines of Th-brabantite are observed [JCPDS File \# 31-311] as a consequence of the reaction between $\mathrm{Ca}\left(\mathrm{PO}_{3}\right)_{2}$ and $\mathrm{ThO}_{2}$. Simultaneously, the XRD lines of $\alpha-\mathrm{ThP}_{2} \mathrm{O}_{7}$ are also observed [JCPDS File \# 16-230]. This intermediate progressively disappears above $900^{\circ} \mathrm{C}$. Between 800 and $900^{\circ} \mathrm{C}$, the system appears thus polyphase and consists on a mixture of $\mathrm{Ca}_{0.5} \mathrm{Th}_{0.5} \mathrm{PO}_{4}$, $\mathrm{Ca}\left(\mathrm{PO}_{3}\right)_{2}, \mathrm{ThO}_{2}$ and $\alpha-\mathrm{ThP}_{2} \mathrm{O}_{7}$ between which several chemical reactions occur leading to the numerous effects observed during the DTA experiments. The thermal effects observed between 700 and $1000^{\circ} \mathrm{C}$ are surely the consequence of several solid-solid reactions between all these compounds. Nevertheless, these effects can not be easily discriminated which contributes to some difficulties in their specific assignment, as already mentioned.

Above $1000^{\circ} \mathrm{C}$, the $\mathrm{XRD}$ patterns correspond to pure and single phase Th-brabantite ${ }^{68}$ which chemical composition is consistent with that expected (Table 2).

Table 2. EPMA results of $\mathrm{Ca}_{0.5} \mathrm{M}_{0.5} \mathrm{PO}_{4}$ synthesized at $1200 \mathrm{~h}$ for 6 hours in inert atmosphere

\begin{tabular}{ccc|cc}
\hline \multicolumn{2}{c|}{$\mathbf{M}=\mathbf{T h}$} & \multicolumn{2}{c}{$\mathbf{M}=\mathbf{U}$} \\
\hline Obs. & Calc. & Obs. & Calc. \\
\hline wt.\% (O) & $25.2 \pm 0.2$ & 27.7 & $28.3 \pm 0.4$ & 27.3 \\
\hline
\end{tabular}




\begin{tabular}{ccc:cc}
\hline wt.\% $(\mathrm{P})$ & $14.0 \pm 0.2$ & 13.4 & $13.6 \pm 0.2$ & 13.24 \\
\hline wt.\% $(\mathrm{Ca})$ & $9.0 \pm 0.1$ & 8.7 & $9.3 \pm 0.1^{*}$ & 8.6 \\
\hline wt.\% $(\mathrm{An})$ & $51.8 \pm 0.6$ & 50.2 & $51.5 \pm 0.8$ & 50.9 \\
\hline $\mathrm{M} / \mathrm{Ca}$ & $1.00 \pm 0.02$ & 1 & $0.94 \pm 0.02^{*}$ & 1 \\
\hline $\mathrm{P} /(\mathrm{Ca}+\mathrm{M})$ & $1.01 \pm 0.01$ & 1 & $0.982 \pm 0.008$ & 1 \\
\hline
\end{tabular}

The spectroscopic characterization of $\mathrm{Ca}_{0.5} \mathrm{Th}_{0.5} \mathrm{PO}_{4}$ through $\mu$-Raman experiments confirms that all the vibration bands observed correspond to $\delta_{\mathrm{S}}(\mathrm{P}-\mathrm{O})\left(400-450 \mathrm{~cm}^{-1}\right), \delta_{\mathrm{AS}}(\mathrm{P}-\mathrm{O})\left(530-650 \mathrm{~cm}^{-1}\right)$, $v_{\mathrm{S}}(\mathrm{P}-\mathrm{O})\left(\approx 980 \mathrm{~cm}^{-1}\right)$ and $v_{\mathrm{AS}}(\mathrm{P}-\mathrm{O})\left(1050-1150 \mathrm{~cm}^{-1}\right)$ associated to $\mathrm{PO}_{4}$ entities as reported in Figure 2.

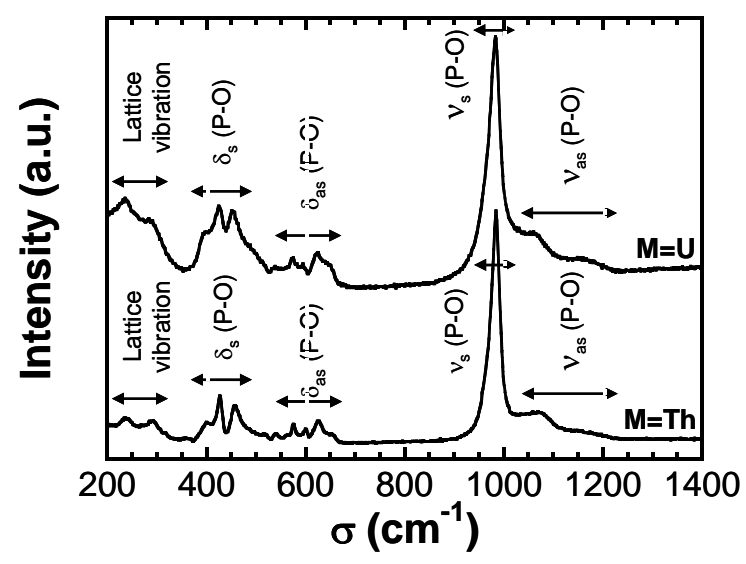

Figure 2. $\quad \mu$-Raman spectra of $\mathrm{Ca}_{0.5} \mathrm{M}_{0.5} \mathrm{PO}_{4}$.

All the data recorded appear in good agreement with that reported in literature. ${ }^{69}$ Moreover, no vibration band associated of the $\mathrm{P}-\mathrm{O}-\mathrm{P}$ bridge characteristic of diphosphate entities or of polytrioxophosphate groups is observed (especially in the range of $700-800 \mathrm{~cm}^{-1}$ ) 70 that confirms the complete reaction between intermediates such as $\alpha-\mathrm{ThP}_{2} \mathrm{O}_{7}$ and $\mathrm{Ca}\left(\mathrm{PO}_{3}\right)_{2}$.

Finally, the crystallinity of the Th-brabantite phase was followed through the determination of the average FWHM of the main XRD lines, corresponding to the $\overline{1} 11,20 \overline{1}, 120,012,20 \overline{2}$ and 112 reflections (Figure 3), and of the refined unit cell parameters (Table 3).

\footnotetext{
* Interferences revealed during analyses, between uranium and calcium, leading to an overestimation of calcium
} 


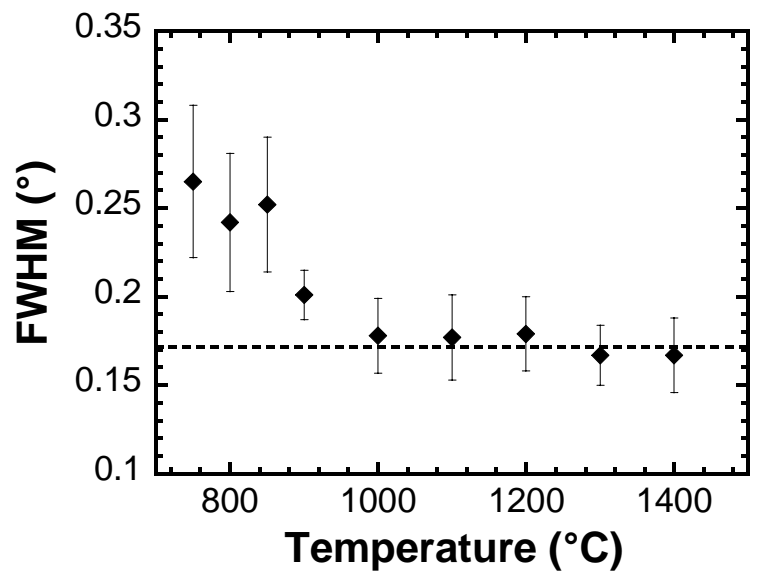

Figure 3. Average FWHM of the main XRD lines (i.e. $\overline{1} 11,20 \overline{1}, 120,012,20 \overline{2}$ and 112 ) of $\mathrm{Ca}_{0.5} \mathrm{Th}_{0.5} \mathrm{PO}_{4}$, versus synthesis temperature.

Table 3. Unit cell parameters of $\mathrm{Ca}_{0.5} \mathrm{M}_{0.5} \mathrm{PO}_{4}$ versus synthesis temperature under Ar atmosphere

\begin{tabular}{|c|c|c|c|c|c|c|c|}
\hline & $\mathbf{T}\left({ }^{\circ} \mathrm{C}\right)$ & a (nm) & b (nm) & c (nm) & $\beta\left(^{\circ}\right)$ & $\begin{array}{l}\times 10^{3} \\
\left(\mathrm{~nm}^{3}\right)\end{array}$ & $\mathbf{F}_{20}$ \\
\hline \multirow{9}{*}{$\mathrm{M}=\mathrm{Th}$} & Podor et al. ${ }^{48}$ & 0.6714 & 0.6921 & 0.6424 & 103.68 & 290.0 & - \\
\hline & 750 & $0.6728(4)$ & $0.6918(3)$ & $0.6432(3)$ & $103.89(4)$ & $290.6(4)$ & $<10$ \\
\hline & 800 & $0.6724(2)$ & $0.6912(3)$ & $0.6419(5)$ & $103.94(4)$ & $289.6(5)$ & $13(0.0017 ; 85)$ \\
\hline & 900 & $0.67156(7)$ & $0.69153(5)$ & $0.64190(6)$ & $103.797(9)$ & $289.5(7)$ & $73(0.0051 ; 54)$ \\
\hline & 1000 & $0.67118(4)$ & $0.69155(5)$ & $0.64170(4)$ & $103.753(6)$ & 289.3(5) & $90(0.0054 ; 41)$ \\
\hline & 1100 & $0.67120(4)$ & $0.69152(5)$ & $0.64168(5)$ & $103.737(7)$ & 289.3(5) & $89(0.0057 ; 39)$ \\
\hline & 1200 & $0.67123(4)$ & $0.69169(5)$ & $0.64163(5)$ & $103.738(6)$ & 289.4(5) & $115(0.0051 ; 34)$ \\
\hline & 1300 & $0.67139(4)$ & $0.69185(5)$ & $0.64201(4)$ & $103.737(6)$ & $289.7(5)$ & $103(0.0050 ; 39)$ \\
\hline & 1400 & $0.67137(4)$ & $0.69181(5)$ & $0.64187(4)$ & $103.732(6)$ & $289.6(5)$ & $96(0.0055 ; 38)$ \\
\hline \multirow{7}{*}{$\mathrm{M}=\mathrm{U}$} & Montel et al. ${ }^{68}$ & 0.6673 & 0.6852 & 0.6364 & 104.07 & 282.3 & - \\
\hline & 900 & $0.6675(2)$ & $0.6853(2)$ & $0.6372(2)$ & $104.10(3)$ & $283(2)$ & $20(0.015 ; 66)$ \\
\hline & 1000 & $0.66728(5)$ & $0.68590(5)$ & $0.63733(6)$ & $104.037(8)$ & $283.0(2)$ & $81(0.0039 ; 63)$ \\
\hline & 1100 & $0.66729(3)$ & $0.68607(4)$ & $0.63755(5)$ & $104.036(6)$ & 283.2(5) & $92(0.0036 ; 61)$ \\
\hline & 1200 & $0.66724(4)$ & $0.68601(5)$ & $0.63766(6)$ & $104.028(8)$ & $283.2(6)$ & $125(0.0039 ; 41)$ \\
\hline & 1300 & $0.66718(4)$ & $0.68596(5)$ & $0.63765(6)$ & $104.025(7)$ & 283.1(6) & $70(0.0047 ; 61)$ \\
\hline & 1400 & $0.66706(3)$ & $0.68607(4)$ & $0.63782(5)$ & $104.020(7)$ & $283.2(5)$ & $85(0.0041 ; 57)$ \\
\hline
\end{tabular}

From these data, it is clear that the cristallinity of Th-brabantite samples is significantly improved when increasing the heating temperature from 750 to $1200^{\circ} \mathrm{C}$, the optimized conditions of preparation being obtained between 1200 and $1300^{\circ} \mathrm{C}$. At these temperatures, the unit cell parameters obtained $(a=$ 
6.7123(4) $\AA, b=6.9169(5) \AA, c=6.4163(5) \AA$ and $\left.\beta=103.738(6)^{\circ}\right)$ appear in good agreement with the data reported in the literature for Th-brabantite samples prepared through other chemical processes which confirms the full incorporation of thorium in the monazite structure through the coupled substitution examined. ${ }^{47,71}$ Finally, at $1400^{\circ} \mathrm{C}$, the refinement of the unit cell parameters seems to indicate the beginning of the thermal decomposition of $\mathrm{Ca}_{0.5} \mathrm{Th}_{0.5} \mathrm{PO}_{4}$, which was especially observed when increasing the heating time at this temperature. For higher heating temperatures, some small amounts of thorium dioxide were also detected at the surface of the samples (especially when working on Th-brabantite pellets), as a consequence of the local decomposition of Th-brabantite into calcium oxide, thorium dioxide and volatile phosphorous oxide $\left(\mathrm{P}_{4} \mathrm{O}_{10}\right)$, according to:

$$
\mathrm{Ca}_{0.5} \mathrm{Th}_{0.5} \mathrm{PO}_{4} \stackrel{\mathrm{T} \geq 1400^{\circ} \mathrm{C}}{\longrightarrow} 1 / 2 \mathrm{CaO}+1 / 2 \mathrm{ThO}_{2}+1 / 4 \mathrm{P}_{4} \mathrm{O}_{10} \uparrow
$$

\subsection{Preparation of $\mathrm{Ca}_{0.5} \mathrm{U}_{0.5} \mathrm{PO}_{4}$}

From the results reported in the previous section, the full incorporation of thorium in the monazite structure appears possible when heating between 1200 and $1300^{\circ} \mathrm{C}$. However, as already discussed, thorium is expected to be only tetravalent in these operating conditions of synthesis. For this reason, the incorporation of uranium which presents several stabilized oxidation states (mainly (IV) and (VI) in phosphoric medium) was also examined. In this aim, mixtures of $\mathrm{UO}_{2}, \mathrm{Ca}\left(\mathrm{HPO}_{4}\right) \cdot 2 \mathrm{H}_{2} \mathrm{O}$ and $\mathrm{NH}_{4} \mathrm{H}_{2} \mathrm{PO}_{4}$ were ground mechanically then fired at several heating temperatures ranging from 400 to $1400^{\circ} \mathrm{C}$.

The first indication of the progression of the solid-solid reaction was deduced from some changes in the colour of the samples which turned from black/grey (due to the presence of $\mathrm{UO}_{2}$ in the mixture) to green (characteristic of the presence of tetravalent uranium in phosphoric compounds) ${ }^{72,73}$ when heating above $900^{\circ} \mathrm{C}$. Such an observation was correlated to the study of the variation of the XRD diagrams versus the heating temperature (Figure 4) which indicates that the incorporation of uranium in the monazite structure follows the same chemical scheme than that reported for thorium. Indeed, after the full dehydration of $\mathrm{Ca}\left(\mathrm{HPO}_{4}\right) \cdot 2 \mathrm{H}_{2} \mathrm{O}$ then the decomposition of $\mathrm{NH}_{4} \mathrm{H}_{2} \mathrm{PO}_{4}$ between $100^{\circ} \mathrm{C}$ and $600^{\circ} \mathrm{C}$, the XRD pattern highlights the presence of $\mathrm{Ca}\left(\mathrm{PO}_{3}\right)_{2}$ and $\alpha-\mathrm{UP}_{2} \mathrm{O}_{7}$ [JCPDS File \# 16-263], as 
intermediates above $700^{\circ} \mathrm{C}$. All the XRD lines of U-brabantite $\left(\mathrm{Ca}_{0.5} \mathrm{U}_{0.5} \mathrm{PO}_{4}\right)$ are observed when heating above $900^{\circ} \mathrm{C}$, correlatively to the decrease of the XRD lines of $\mathrm{UO}_{2}$ [JCPDS File \# 41-1422]. At this temperature, the $\mathrm{Ca}_{0.5} \mathrm{U}_{0.5} \mathrm{PO}_{4}$ phase [JCPDS File \# 12-279] coexists with $\mathrm{UO}_{2}$ and $\alpha-\mathrm{UP}_{2} \mathrm{O}_{7}$ which fully disappear at $900^{\circ} \mathrm{C}$ and $1000^{\circ} \mathrm{C}$, respectively.

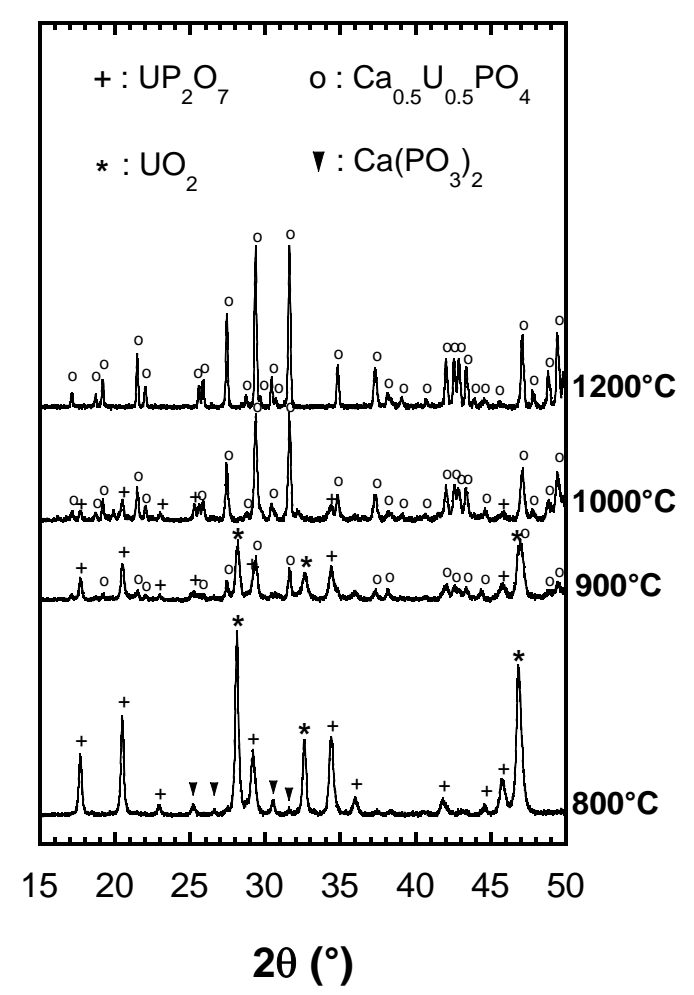

Figure 4. $\mathrm{X}$-ray diffraction analysis of a $\mathrm{UO}_{2}-\mathrm{Ca}\left(\mathrm{HPO}_{4}\right) \cdot 2 \mathrm{H}_{2} \mathrm{O}-\mathrm{NH}_{4} \mathrm{H}_{2} \mathrm{PO}_{4}$ mixture.

Pure and single phase samples of $\mathrm{U}-$ brabantite are thus obtained when heating above $1100^{\circ} \mathrm{C}$. At this temperature, the elementary composition determined from EPMA appears in good agreement with that expected (Table 2) while the unit cell parameters determined (Table 3) seems to confirm the incorporation of tetravalent uranium in the monazite structure. ${ }^{48}$

The comparison of the $\mu$-Raman spectra of $\mathrm{Ca}_{0.5} \mathrm{Th}_{0.5} \mathrm{PO}_{4}$ and $\mathrm{Ca}_{0.5} \mathrm{U}_{0.5} \mathrm{PO}_{4}$ does not reveal any significant differences (Figure 2). The positions of the vibration bands are very close, particularly the strong one located around $980 \mathrm{~cm}^{-1}$ (which can be assigned to $v_{\mathrm{S}}(\mathrm{P}-\mathrm{O})$ in phosphate groups). As for Th-brabantite, it is worth noting that the vibrations usually associated to diphosphate or 
polytrioxophosphate groups are not observed, as a confirmation of the complete reaction of the intermediates formed at lower temperatures $\left(\alpha-\mathrm{UP}_{2} \mathrm{O}_{7}\right.$ or $\left.\mathrm{Ca}\left(\mathrm{PO}_{3}\right)_{2}\right)$. Moreover, the absence of intense and narrow vibration band in the domain $850-870 \mathrm{~cm}^{-1}$, characteristic of the $v_{1}$ symmetric stretching mode of uranyl units $\left(\mathrm{UO}_{2}{ }^{2+}\right)^{74,76}$ confirms the stabilization of tetravalent uranium during all the synthesis process which was suggested by the colour of all the final samples prepared, as already discussed. These results appear in contradiction with that reported by Mc Carthy et al. ${ }^{77}$ who observed the oxidation of uranium (IV) during the heating treatment and also with the data associated to the synthesis of $\mathrm{U}$-britholites ${ }^{3}$ which revealed the formation of $\mathrm{CaUO}_{4}$ then $\mathrm{CaU}_{2} \mathrm{O}_{5+y}$ through a complex redox uranium cycle.

As it was observed for Th-brabantite, the cristallinity of U-brabantite is significantly improved when increasing the heating temperature from 900 to $1200^{\circ} \mathrm{C}$ (decrease of the average $\mathrm{FWHM}$ and improvement in the unit cell parameters refinement). Above $1300^{\circ} \mathrm{C}$, the beginning of the decomposition of U-brabantite is observed, leading to the formation of uranium dioxide (which can be evidenced by the change in colour form green to grey/black). This decomposition is particularly observed at the surface of U-brabantite pellets which are finally recovered by this thin black/grey uranium oxide layer when extending the heating time. As already discussed for Th-brabantite, the associated reaction of decomposition can thus be written:

$$
\mathrm{Ca}_{0.5} \mathrm{U}_{0.5} \mathrm{PO}_{4} \stackrel{\mathrm{T} \geq 1300^{\circ} \mathrm{C}}{\longrightarrow} 1 / 2 \mathrm{CaO}+1 / 2 \mathrm{UO}_{2}+1 / 4 \mathrm{P}_{4} \mathrm{O}_{10} \uparrow
$$

On the basis of the results obtained when studying the formation of Th-brabantite and U-brabantite from mixtures of $\mathrm{MO}_{2}(\mathrm{M}=\mathrm{Th}, \mathrm{U}), \mathrm{Ca}\left(\mathrm{HPO}_{4}\right) \cdot 2 \mathrm{H}_{2} \mathrm{O}$ and $\mathrm{NH}_{4} \mathrm{H}_{2} \mathrm{PO}_{4}$, a simplified chemical mechanism was proposed (Figure 5). 

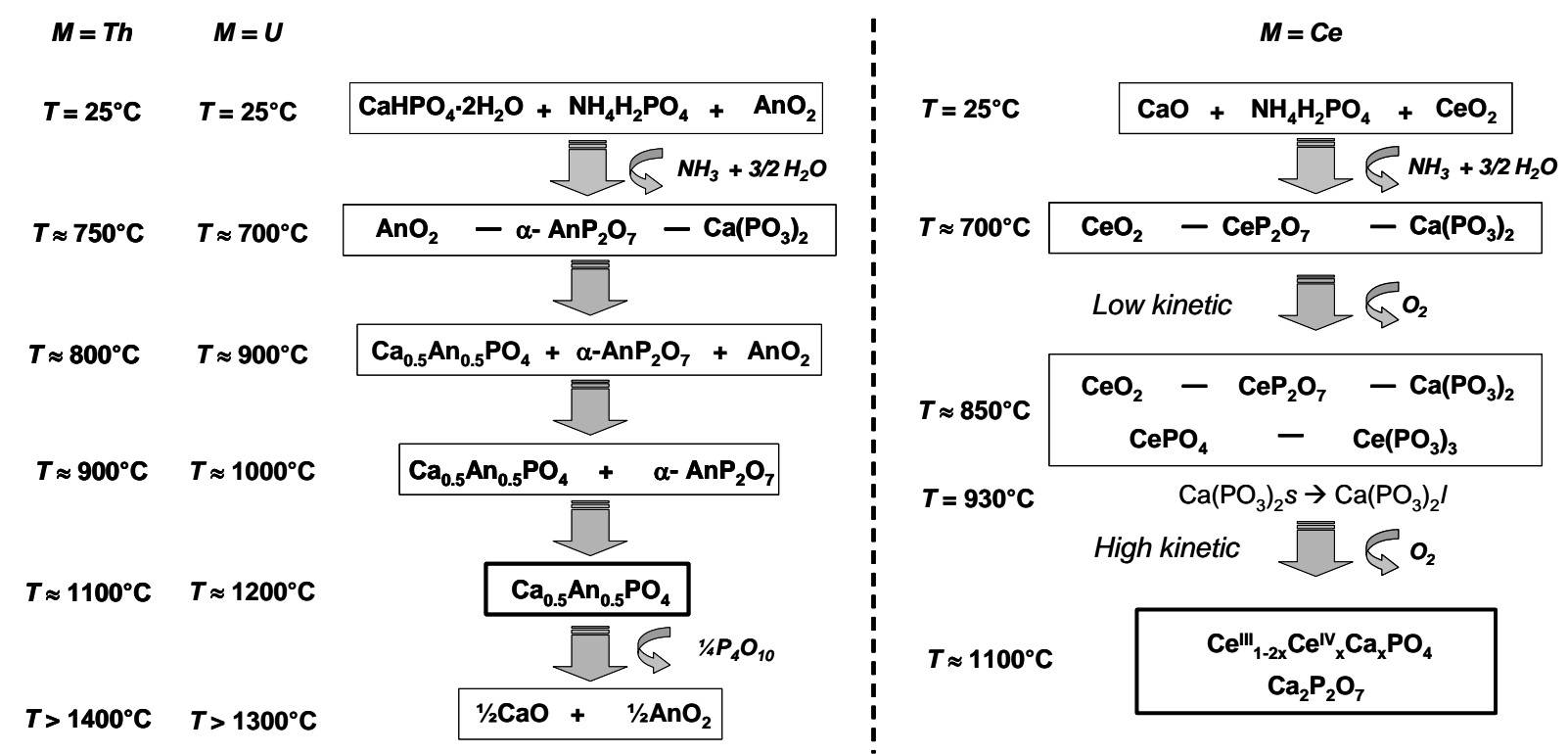

Figure 5. Thermal behavior of the starting mixture under argon atmosphere (for Th and U) or in air (for $\mathrm{Ce})$.

\subsection{Synthesis of $\mathrm{Ca}_{0.5} \mathrm{Ce}_{0.5} \mathrm{PO}_{4}$}

As uranium, plutonium could exist with two stabilized oxidation states (III and IV) in the phosphate environment. However, the trivalent oxidation state appears as the most favorable plutonium oxidation state in the monazite structure. Nevertheless, it is questionable if $\mathrm{Pu}(\mathrm{IV})$ could exist in such a structure when calcium is simultaneously incorporated. Because of the radiotoxicity of plutonium, experiments were first developed with cerium as a surrogate, since cerium presents similar properties with plutonium, both in terms of ionic size and redox properties. To this aim, the thermal behavior of a $\mathrm{CeO}_{2}-\mathrm{CaO}-2 \mathrm{NH}_{4} \mathrm{H}_{2} \mathrm{PO}_{4}$ mixture was investigated.

The physical and chemical phenomena occurring during the calcination of the starting mixture were followed by thermal analysis and by XRD for $\mathrm{Ca}_{0.5} \mathrm{Ce}_{0.5} \mathrm{PO}_{4}$ (Figure 6). 

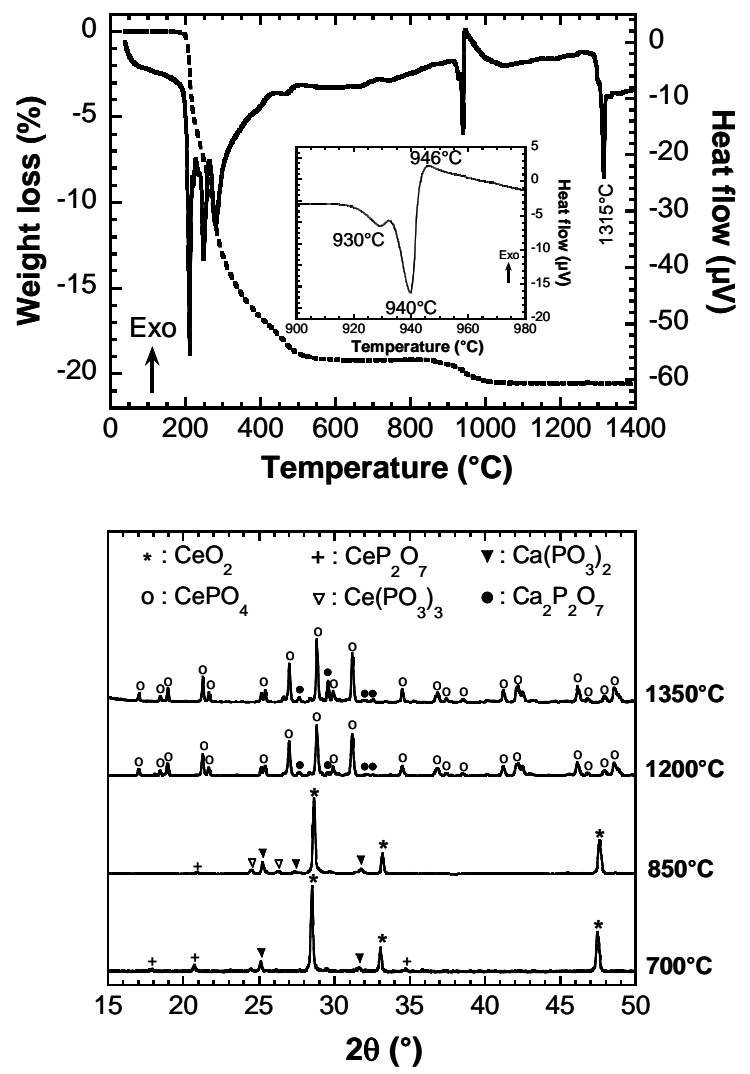

Figure 6. Thermal analysis under air and $\mathrm{X}$-ray diffraction of $\mathrm{CeO}_{2}-\mathrm{CaO}-2 \mathrm{NH}_{4} \mathrm{H}_{2} \mathrm{PO}_{4}$ mixture.

From room temperature to $800^{\circ} \mathrm{C}$, several thermal effects and an important weight loss were observed, all assigned to the thermal decomposition of $\mathrm{NH}_{4} \mathrm{H}_{2} \mathrm{PO}_{4}$ into $\mathrm{NH}_{3}$ and $\mathrm{H}_{2} \mathrm{O}$, as previously observed for thorium (see section 3.1.). The observed weight loss $(19.23 \%)$ is very close to the expected value $(19.22 \%)$. Beyond $800^{\circ} \mathrm{C}, 4$ thermal effects $\left(930^{\circ} \mathrm{C}, 940^{\circ} \mathrm{C}, 946^{\circ} \mathrm{C}\right.$ and $\left.1315^{\circ} \mathrm{C}\right)$ and an additional weight loss $\left(1.44 \%\right.$ between $800^{\circ} \mathrm{C}$ and $\left.1050^{\circ} \mathrm{C}\right)$ could be observed. With the TG derivative curve, not plotted on this graph, the latter can be assigned as the second endothermic effect occurring at $940^{\circ} \mathrm{C}$. The analysis of the emitted gas by mass spectrometry revealed that this weight loss is due to a dioxygen emission. As already described for thorium and uranium, the XRD patterns revealed the presence of monazite and of calcium diphosphate $\mathrm{Ca}_{2} \mathrm{P}_{2} \mathrm{O}_{7}$ [JCPDS File \# 73-0440], as previously described by Pepin et al. ${ }^{61}$ Moreover, three other phosphates could be observed as transient compounds: $\mathrm{CeP}_{2} \mathrm{O}_{7}$ [JCPDS File \# 30-0164] and $\mathrm{Ca}\left(\mathrm{PO}_{3}\right)_{2}$ at $700^{\circ} \mathrm{C}$ and $850^{\circ} \mathrm{C}$, and $\mathrm{Ce}\left(\mathrm{PO}_{3}\right)_{3}[\mathrm{JCPDS}$ File \# 33-0336] at $850^{\circ} \mathrm{C}$. Melting points of $\mathrm{Ca}\left(\mathrm{PO}_{3}\right)_{2}$ and $\mathrm{Ca}_{2} \mathrm{P}_{2} \mathrm{O}_{7}$, measured by thermal analysis, was found to be located 
at $985^{\circ} \mathrm{C}$ and $1318^{\circ} \mathrm{C}$, respectively. From these results, the qualitative mechanism of reaction can be proposed (Figure 5). The reactions can be sorted into two categories:

(a) Solid state reactions $\left(\mathrm{T}<930^{\circ} \mathrm{C}\right)$

- $\quad$ From $40^{\circ} \mathrm{C}$ to $840^{\circ} \mathrm{C}$, the phosphate precursor melts and decomposes with emission of $\mathrm{NH}_{3}$ and $\mathrm{H}_{2} \mathrm{O}$ before reacting with $\mathrm{CaO}$ and $\mathrm{CeO}_{2}$ to form $\mathrm{Ca}\left(\mathrm{PO}_{3}\right)_{2}$ and $\mathrm{CeP}_{2} \mathrm{O}_{7}$ :

$$
2 \mathrm{NH}_{4} \mathrm{H}_{2} \mathrm{PO}_{4}+\mathrm{CaO}+\mathrm{CeO}_{2} \rightarrow \mathrm{Ca}\left(\mathrm{PO}_{3}\right)_{2}+\mathrm{CeP}_{2} \mathrm{O}_{7}+2 \mathrm{NH}_{3} \uparrow+3 \mathrm{H}_{2} \mathrm{O} \uparrow
$$

- $\quad$ From $840^{\circ} \mathrm{C}$ to $930^{\circ} \mathrm{C}$, a slight weight loss is observed on the TG curve (Figure 6). According to literature, this results of the slow decomposition of $\alpha-\mathrm{CeP}_{2} \mathrm{O}_{7}:^{1,78,79}$

$$
2 \mathrm{CeP}_{2} \mathrm{O}_{7} \rightarrow \mathrm{Ce}\left(\mathrm{PO}_{3}\right)_{3}+\mathrm{CePO}_{4}+1 / 2 \mathrm{O}_{2} \uparrow
$$

The oxygen emission appears as the consequence of the reduction of the $\mathrm{Ce}(\mathrm{IV})$ into $\mathrm{Ce}(\mathrm{III})$.

(b) Liquid state reactions $\left(930^{\circ} \mathrm{C}<\mathrm{T}<1050^{\circ} \mathrm{C}\right)$

- At $930^{\circ} \mathrm{C}, \mathrm{Ca}\left(\mathrm{PO}_{3}\right)_{2}$ melts (DTA effect at $930^{\circ} \mathrm{C}$ ) and dissociates into $\mathrm{Ca}^{2+}$ and $\mathrm{PO}_{3}{ }^{-}:^{80}$

$$
\mathrm{Ca}\left(\mathrm{PO}_{3}\right)_{2(\mathrm{~s})} \rightarrow\left[\mathrm{Ca}^{2+}+2 \mathrm{PO}_{3}^{-}\right]_{\ell}
$$

- In such an ionic liquid, the $\mathrm{Ce}-\mathrm{O}$ chemical bond of $\mathrm{CeO}_{2}$ is probably broken ${ }^{80}$ Consequently, the liquid phase consists of 4 ions, i.e. $\mathrm{Ca}^{2+}+2 \mathrm{PO}_{3}{ }^{-}+\mathrm{Ce}^{4+}+\mathrm{O}^{2-}$. Immediately, the kinetic of the reduction of $\mathrm{Ce}^{4+}$ strongly increases (DTA effect at $940^{\circ} \mathrm{C}$ ). Consecutively, a slow precipitation of two phases occurs (wide DTA effect at $946^{\circ} \mathrm{C}$ ):

$$
\left[\mathrm{Ca}^{2+}+\mathrm{Ce}^{3+}+2 \mathrm{PO}_{3}^{-}+3 / 2 \mathrm{O}^{2-}\right]_{\ell} \rightarrow \mathrm{CePO}_{4(\mathrm{~s})}+{ }^{1 / 2} \mathrm{Ca}_{2} \mathrm{P}_{2} \mathrm{O}_{7(\mathrm{~s})}
$$

The DTA effect observed at $1315^{\circ} \mathrm{C}$ can thus be assigned to the melting of $\mathrm{Ca}_{2} \mathrm{P}_{2} \mathrm{O}_{7}$. In conclusion, the chemical reaction occurring during the calcination of a $\mathrm{CeO}_{2}-\mathrm{CaO}-2 \mathrm{NH}_{4} \mathrm{H}_{2} \mathrm{PO}_{4}$ is, with the assumption that it is a total reaction:

$$
\mathrm{CeO}_{2}+\mathrm{CaO}+2 \mathrm{NH}_{4} \mathrm{H}_{2} \mathrm{PO}_{4} \rightarrow \mathrm{CePO}_{4}+1 / 2 \mathrm{Ca}_{2} \mathrm{P}_{2} \mathrm{O}_{7}+2 \mathrm{NH}_{3} \uparrow+3 \mathrm{H}_{2} \mathrm{O} \uparrow+1 / 4 \mathrm{O}_{2} \uparrow
$$

However, several experiments indicate that the reaction reported in (eq 15) is not complete and that the powder contains both trivalent and tetravalent cerium. The resulting powder exhibits a green color, 
as observed by Heindl et al., ${ }^{60}$ whereas $\mathrm{CePO}_{4}$ is usually white colored. Moreover, the unit cell parameters are smaller $(a=6.711 \AA, b=7.036 \AA$ and $c=6.384 \AA)$ than that reported for pure $\mathrm{CePO}_{4}(a$ $=6.800 \AA, b=7.024 \AA$ and $c=6.474 \AA),{ }^{1}$ which appears in agreement with the partial incorporation of $\mathrm{Ce}(\mathrm{IV})$ in the monazite structure, since $1 / 2\left(\mathrm{Ce}^{\mathrm{IV}}+\mathrm{Ca}^{\mathrm{II}}\right)$ is smaller than $\mathrm{Ce} \mathrm{e}^{\mathrm{III}}(1.10 \AA$ and $1.196 \AA$, respectively). ${ }^{64}$ The presence of $\mathrm{Ce}^{\mathrm{IV}}$ in the monazite structure was highlighted without any ambiguity by EELS (Figure 7).
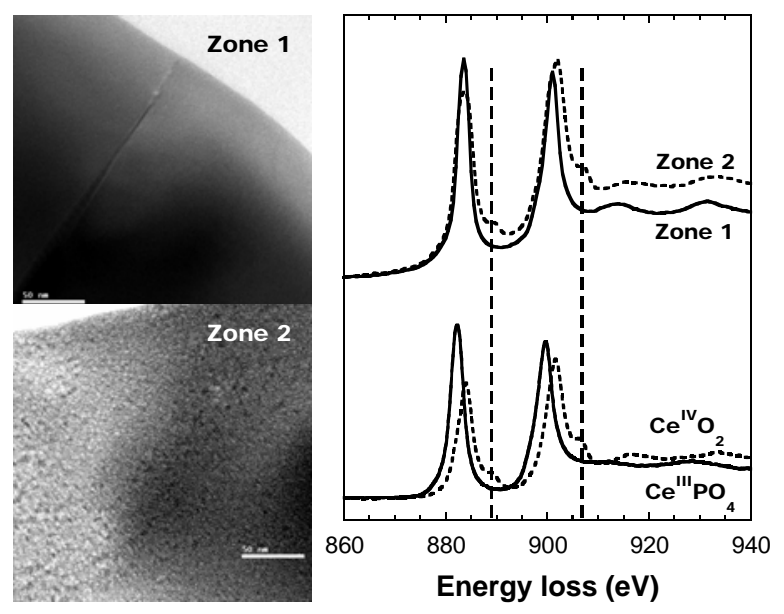

Figure 7. TEM observation and cerium EELS spectra of $\mathrm{M}_{4,5}$-edge fine structure of $\mathrm{CeO}_{2}-\mathrm{CaO}-$ $2 \mathrm{NH}_{4} \mathrm{H}_{2} \mathrm{PO}_{4}$ mixture fired at $1400^{\circ} \mathrm{C}$.

Two different types of zones were observed by TEM. The first one appears with a uniform contrast and an amorphous structure (Zone 1 on Figure 7), while in the second one, cristallized nanostructures were observed (Zone 2 on Figure 7). The analysis of the fine structure of the cerium $\mathrm{M}_{4,5}-\mathrm{edge}$ doublet leads to several remarks:

- the spectra of Zone 1 is characteristic of trivalent cerium;

- the shift of the doublet toward the high energies, the extra shoulders observed in Zone 2 spectra and the inversion of the intensity ratio between the two peaks prove the presence of $\mathrm{Ce}(\mathrm{IV})$ in this zone, in agreement with experiments performed on $\mathrm{Ce}^{\mathrm{III}}$ and $\mathrm{Ce}^{\mathrm{IV}}$ references samples and with litterature. ${ }^{81,82}$ Moreover, calcium is only detected in the Zone 2, which is consistent with the presence of $\mathrm{Ce}^{\mathrm{IV}}$ in this zone. 


\subsection{Incorporation of $\mathrm{Ce}^{\mathrm{IV}}$ in $(\mathrm{La}, \mathrm{Ce}){ }^{\mathrm{III}} \mathrm{PO}_{4}$ solid solution}

The previous results highlight that only a small amount of tetravalent cerium could be incorporated in the monazite structure. Two hypotheses could explain this incomplete incorporation: tetravalent cerium is unstable in monazite because of redox properties, or the $\left(\mathrm{Ce}^{\mathrm{IV}}, \mathrm{Ca}^{\mathrm{II}}\right)$ couple is too small to incorporate the monazite structure. In that case, the incorporation should be linked to the global cationic size. Thus, the $\mathrm{Ce}^{\mathrm{IV}} / \mathrm{Ce}$ III ratio should be higher in a $\mathrm{LaPO}_{4}$ matrix than in a $\mathrm{CePO}_{4}$ one. Consequently, the incorporation of the $\left(\mathrm{Ce}^{\mathrm{IV}}, \mathrm{Ca}\right.$ II $)$ couple is investigated in the $\mathrm{LaPO}_{4}-\mathrm{CePO}_{4}$ solid solution:

$$
\begin{aligned}
& 1 / 2(1-2 x) \mathrm{La}_{2} \mathrm{O}_{3}+x \mathrm{CeO}_{2}+x \mathrm{CaO}+\mathrm{NH}_{4} \mathrm{H}_{2} \mathrm{PO}_{4} \rightarrow \mathrm{La}_{1-2 x} \mathrm{Ce}^{\mathrm{III}}{ }_{x-y} \mathrm{Ce}^{\mathrm{IV}}{ }_{y} \mathrm{Ca}_{y}\left(\mathrm{PO}_{4}\right)_{1-x+y}+1 / 2(x-y) \mathrm{Ca}_{2} \mathrm{P}_{2} \mathrm{O}_{7}+ \\
& \mathrm{NH}_{3} \uparrow+1 / 2 \mathrm{H}_{2} \mathrm{O} \uparrow+1 / 4(1-2 x) \mathrm{O}_{2} \uparrow
\end{aligned}
$$

The measurement of $\mathrm{Ce}^{\mathrm{IV}} / \mathrm{Ce}^{\mathrm{III}}$ ratio was obtained by using two methods:

(a) EPMA experiments: in the monazite phase, the amount of tetravalent cerium was determined by measuring both $\mathrm{Ca}$ and $\mathrm{Ce}$ contents, noted $(\mathrm{Ca})$ and $(\mathrm{Ce})$, respectively, with the assumption that $\mathrm{Ca}^{2+}$ acts as the only charge compensation mechanism. The $\mathrm{Ce}^{\mathrm{IV}} / \mathrm{Ce}^{\mathrm{III}}$ mole ratio is thus given by the following relationship:

$$
\frac{\mathrm{Ce}^{\mathrm{IV}}}{\mathrm{Ce}^{\mathrm{III}}}=\frac{(\mathrm{Ca})}{(\mathrm{Ce})-(\mathrm{Ca})}
$$

This method is all the more accurate than (Ce) and (Ca) is high (i.e. for high $x$ values). For the samples examined in this work, EPMA was not suitable for $x<0.2$.

(b) XRD analysis: this method was based on the refinement of the unit cell parameters of the monazite phase from which it is possible to deduce the average cationic radius $\overline{{ }^{I X} r\left(\mathrm{M}^{\mathrm{III}+\mathrm{II}+\mathrm{IV}}\right)}$ considering, as instance, the following relation: ${ }^{1}$

$$
\overline{{ }^{I X} r\left(\mathrm{M}^{\mathrm{III+II+IV}}\right)}=\frac{\mathrm{a}-0.4718}{1.7420}
$$

with:

$$
\frac{{ }^{I X} r\left(\mathrm{M}^{\mathrm{III}+\mathrm{II}+\mathrm{IV}}\right)}{{ }^{2}}=\frac{(1-2 \mathrm{x}) \times{ }^{I X} \mathrm{r}_{\mathrm{La}}+\mathrm{y} \times{ }^{I X} \mathrm{r}_{\mathrm{Ce}^{\mathrm{IV}}}+\mathrm{y} \times{ }^{I X} \mathrm{r}_{\mathrm{Ca}^{\mathrm{II}}}+(\mathrm{x}-\mathrm{y}) \times{ }^{I X} \mathrm{r}_{\mathrm{Ce}}{ }^{\mathrm{III}}}{1-\mathrm{x}+\mathrm{y}}
$$


which allows the determination of $y$ according to:

$$
\mathrm{y}=\frac{(1-2 \mathrm{x}) \times{ }^{I X} \mathrm{r}_{\mathrm{La}}+\mathrm{x} \times{ }^{I X} \mathrm{r}_{\mathrm{C}^{\mathrm{III}}}-(1-\mathrm{x}) \times{ }^{I X} r\left(\mathrm{M}^{\mathrm{III}+\mathrm{II}+\mathrm{IV}}\right)}{{ }^{I X} r\left(\mathrm{M}^{\mathrm{III}+\mathrm{II}+\mathrm{IV}}\right)-{ }^{I X} \mathrm{r}_{\mathrm{Ce}^{\mathrm{IV}}}-{ }^{I X} \mathrm{r}_{\mathrm{Ca}^{\mathrm{II}}}+{ }^{I X} \mathrm{r}_{\mathrm{Ce}} \mathrm{Ce}^{\mathrm{III}}}
$$

Based on the unit cell parameters determined, this method exhibits a constant accuracy, whatever the $x$ value considered.

All the results reveal the presence of tetravalent cerium in monazite/brabantite samples (Table 4, Figure 8). Nevertheless, the incorporation rate appears weak, i.e. $\mathrm{Ce}^{\mathrm{IV}} /\left(\sum\right.$ cations $)<10 \%$, which is lower from the expected value (47\%), exclusively obtained on the basis of sterical criteria (eqs 3-4 and Table 1).

Table 4. Determination of $\mathrm{Ce}^{\mathrm{IV}} / \mathrm{Ce}^{\mathrm{III}}$ in monazite by XRD and EPMA

\begin{tabular}{|c|c|c|c|c|c|c|c|}
\hline \multirow[b]{2}{*}{$\mathbf{x}$} & \multicolumn{3}{|c|}{ XRD } & \multicolumn{4}{|c|}{ EPMA } \\
\hline & $\overline{{ }^{I X} r}$ (§̊) & $y$ & $\mathrm{Ce}^{\mathrm{IV}} / \mathrm{Ce}^{\mathrm{III}}$ & (Ca) & (Ce) & $y$ & $\mathrm{Ce}^{\mathrm{IV}} / \mathrm{Ce}^{\mathrm{III}}$ \\
\hline 0.04 & $1.214 \pm 0.001$ & $0.007 \pm 0.001$ & $0.20 \pm 0.01$ & $0.018 \pm 0.004$ & $0.035 \pm 0.008$ & $0.02 \pm 0.01$ & $1.0 \pm 0.7$ \\
\hline 0.06 & - & - & - & $0.018 \pm 0.002$ & $0.04 \pm 0.02$ & $0.02 \pm 0.01$ & $0.6 \pm 0.4$ \\
\hline 0.08 & $1.212 \pm 0.001$ & $0.010 \pm 0.001$ & $0.15 \pm 0.01$ & $0.018 \pm 0.002$ & $0.086 \pm 0.008$ & $0.017 \pm 0.004$ & $0.28 \pm 0.1$ \\
\hline 0.10 & $1.211 \pm 0.001$ & $0.013 \pm 0.001$ & $0.15 \pm 0.01$ & $0.019 \pm 0.002$ & $0.091 \pm 0.008$ & $0.021 \pm 0.005$ & $0.27 \pm 0.09$ \\
\hline 0.15 & $1.210 \pm 0.001$ & $0.011 \pm 0.001$ & $0.08 \pm 0.01$ & - & - & - & - \\
\hline 0.20 & $1.206 \pm 0.001$ & $0.020 \pm 0.001$ & $0.11 \pm 0.01$ & $0.027 \pm 0.002$ & $0.25 \pm 0.04$ & $0.022 \pm 0.005$ & $0.12 \pm 0.04$ \\
\hline 0.25 & $1.205 \pm 0.001$ & $0.017 \pm 0.001$ & $0.07 \pm 0.01$ & - & - & - & - \\
\hline 0.30 & $1.203 \pm 0.001$ & $0.015 \pm 0.001$ & $0.05 \pm 0.01$ & $0.040 \pm 0.007$ & $0.416 \pm 0.02$ & $0.029 \pm 0.006$ & $0.12 \pm 0.04$ \\
\hline 0.35 & $1.198 \pm 0.001$ & $0.023 \pm 0.001$ & $0.07 \pm 0.01$ & - & - & - & - \\
\hline 0.40 & $1.198 \pm 0.001$ & $0.015 \pm 0.001$ & $0.04 \pm 0.01$ & $0.040 \pm 0.005$ & $0.81 \pm 0.07$ & $0.020 \pm 0.004$ & $0.06 \pm 0.02$ \\
\hline 0.50 & $1.188 \pm 0.001$ & $0.022 \pm 0.001$ & $0.05 \pm 0.01$ & $0.050 \pm 0.007$ & $0.95 \pm 0.01$ & $0.026 \pm 0.004$ & $0.06 \pm 0.01$ \\
\hline
\end{tabular}




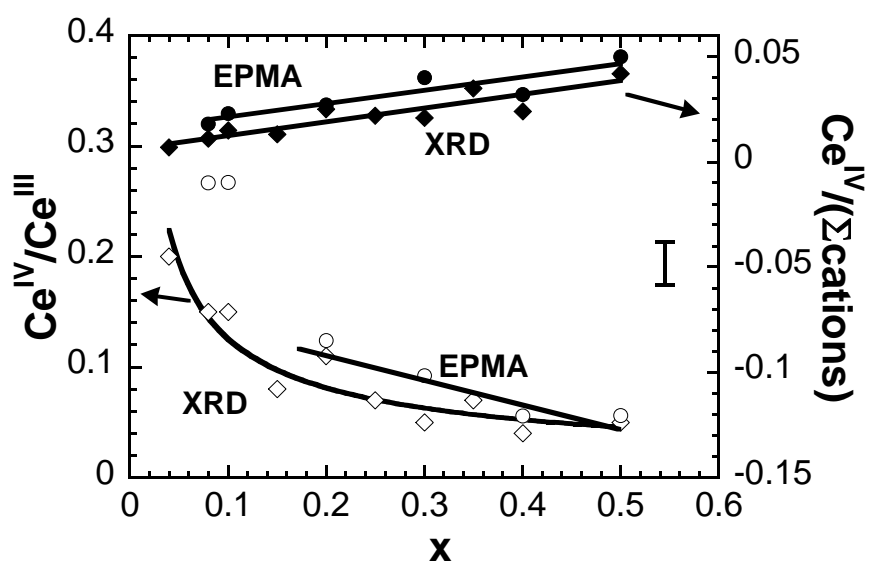

Figure 8. Incorporation of $\mathrm{Ce}^{\mathrm{IV}}$ in $(\mathrm{La}, \mathrm{Ce})^{\mathrm{III}} \mathrm{PO}_{4}$ solid solution

Moreover, $\mathrm{Ce}^{\mathrm{IV}} /\left(\sum\right.$ cations $)$ does not appears as a function of $x$. This highlights that the incorporation of the tetravalent form of an element in the monazite crystal structure is governed by the redox potential of the $\mathrm{M}^{4+} / \mathrm{M}^{3+}$ couple with regard to $\mathrm{O}_{2} / \mathrm{O}^{2-}$. Unfortunately, the redox potentials of the $\mathrm{M}^{4+} / \mathrm{M}^{3+}$ couples remain unknown in the conditions of synthesis considered. Nevertheless, it is possible to discuss on the basis of the values at $25^{\circ} \mathrm{C}-1 \mathrm{~atm} .{ }^{83}$ In these conditions, the redox potential of $\mathrm{Pu}^{4+} / \mathrm{Pu}^{3+}$ and $\mathrm{Ce}^{4+} / \mathrm{Ce}^{3+}$ are close to $\mathrm{O}_{2} / \mathrm{O}^{2-}(1.006 \mathrm{~V}, 1.72 \mathrm{~V}$ and $1.12 \mathrm{~V}$, respectively), which is in accordance with the existence of monazite containing both tri- and tetravalent cerium (this work) and plutonium. ${ }^{16}$ Since the coexistence of the $\mathrm{M}^{\mathrm{IV}}$ and $\mathrm{M}^{\mathrm{III}}$ in monazite is all the more important as the redox potential of the $\mathrm{M}^{4+} / \mathrm{M}^{3+}$ couple is close the one of $\mathrm{O}_{2} / \mathrm{O}^{2-}$, this can also easily explain why $\mathrm{Pu}^{\mathrm{IV}}$ is incorporated in $\mathrm{LaPO}_{4}$ at an higher level than $\mathrm{Ce}^{\mathrm{IV}}\left(\mathrm{M}^{\mathrm{IV}} / \mathrm{M}^{\mathrm{IV}}+\mathrm{M}^{\mathrm{III}}=0.5\right.$ for plutonium and 0.1 for cerium, respectively).

\section{Conclusion}

Acknowledgment. The authors are grateful to Johan Ravaux and Alain Kolher from LCSM (Université Henri Poincaré Nancy-I, France) for performing EPMA and SEM experiments and to Thérèse Lhomme from CREGU (Université Henri Poincaré Nancy-I, France) for her extensive help 
during the characterization of the samples by the $\mu$-Raman technique. This work was financially and scientifically supported by the French Research Group NOMADE (GdR 2023, CNRS/CEA/COGEMA) and by a CEA-CFR research grant.

\section{TOC GRAPHIC}

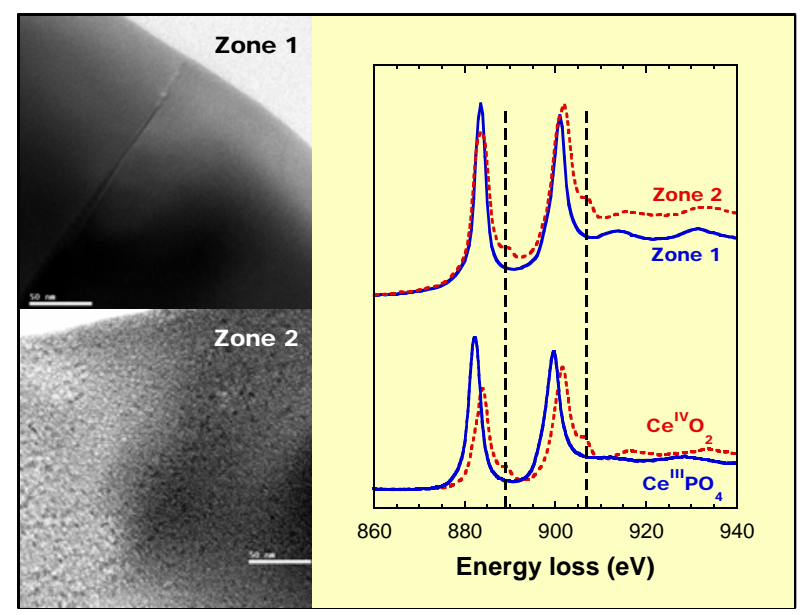

(1) Bregiroux, D.; Audubert, F.; Charpentier, T.; Sakellariou, D.; Bernache-Assollant, D. Solid State Sci. 2007, 9, 432-439.

(2) Terra O., Audubert F., Dacheux N. Guy C. and Podor R., J. Nucl. Mater., 354 (2006) 49.

(3) Terra O., Audubert F., Dacheux N. Guy C. and Podor R., J. Nucl. Mater., 366 (2007) 70.

(4) Clavier N., Dacheux N., Podor R., Inorg. Chem., 45 (2006) 220.

(5) Dacheux N., Clavier N., Robisson A.C., Terra O., Audubert F., Lartigue J.E., Guy C., C.R. Acad. Sc. Paris, 7 (2004) 1141.

(6) Boatner L.A., Beall G.W., Abraham M.M., Finch C.B., Hurray P.G., Rappaz M., in : “Scientific Basis for Nuclear Waste Management”, Eds C.J.M. Northrup Jr., New York, Vol. 2, 289, 1980.

(7) Terra O., Dacheux O., Audubert F. and Podor R., J. Nucl. Mater., 352 (2006) 224.

(8) Terra O., Clavier N., Dacheux N., Podor R., New J. Chem., 27 (2003) 957. 
(9) Poitrasson F., Oelkers E.H., Schott J. and Montel J.-M., Geochim. Cosmchim. Acta, 68 (2004) 2207.

(10) Oelkers E.H. and Poitrasson F., Chem. Geol., 191 (2002) 73.

(11) Cetiner Z.S., Wood S.A. and Gammons C.H., Chem. Geol., 217 (2005) 147.

(12) Ewing R.C. and Haaker R.F., Nuclear and Chemical Waste Management, 1 (1980) 51.

(13) Karioris F.G., Appaji Gowda K. and Cartz L., Rad. Eff. Lett., 58(1-2) (1981) 1

(14) Meldrum A., Boatner L.A., Weber W.J. and Ewing R.C., Geochim. Cosmochim. Acta, 62 (1998) 2509.

(15) Burakov B.E., Yagovkina M.A., Garbuzov V.M., Kitsay, A.A. and Zirlin V.A., Mater. Res. Soc. Symp. Proc., 824 (2004) 219.

(16) Bregiroux D., Belin R., Valenza P., Audubert F., Bernache-Assollant D., J. Nucl. Mater. 366 (2007) 52 .

(17) Deschanels X. Evaluation de la Faisabilité Technique des Nouvelles Matrices de Conditionnement des Radionucléides à Vie Longue; Technical Report DTCD/2004/5; Commissariat à l'Energie Atomique (CEA)-Département d'Etudes du Traitement et du Conditionnement des Déchets (DTCD): Paris, 2004.

(18) Su M.Z., Zhou J. and Shao K.-S., J. Alloys Compd, 207-208 (1994) 406.

(19) Onoda H., Nariai H., Maki H. and Motooka I., Mater. Chem. Phys., 73 (2002) 19.

(20) Hikichi Y., Mineral. J., 15 (1991) 268.

(21) Hikichi Y., Nomura T., Tanimura Y. and Suzuki S., J. Am. Ceram. Soc., 73 (1990) 3594.

(22) Hikichi Y. and Ota T., Phosph. Res. Bull., 6 (1996) 175. 
(23) Bregiroux D., Lucas S., Champion E., Audubert F. and Bernache-Assollant D., J. Eur. Ceram. Soc., 26 (2005) 279.

(24) Bregiroux D., Audubert F. and Bernache-Assollant D., Adv. Sci. Tech., 45 (2006) 633.

(25) Förster H.J., Am. Mineral., 83 (1998) 259.

(26) Gramaccioli C.M. and Segalstad T.M., Am. Mineral., 63 (197(8) 757.

(27) Boatner L.A., in : « Review in mineralogy and chemistry », 48 (2002) 87.

(28) Montel J.M., Kornprobst J., Vielzeuf D., J. Metamorph. Geol., 3 (2000) 335.

(29) Förster H.J., Harlov D.E., Mineralogical Magazine, 63 (1999) 587.

(30) Kucha H., Mineral. Mag., 43 (1980) 1031.

(31) Rose R., N. Jb. Miner. Mh., H(6) (1980) 247.

(32) Van Emden B., Thornber M.R., Graham J. and Lincoln F.J., Can. Mineral., 35 (1997) 95.

(33) Rose D., N. Jb. Miner. Mh., H6 (1980) 247.

(34) Mazeina L., Ushakov S.V., Navrotsky A. and Boatner L.A., Geochim. Cosmochim. Acta, 69 (2005) 4675.

(35) Hoekstra H.R. and Fuchs L.H., Science, 123 (1956) 105.

(36) Fuchs L.H. and Hoekstra H.R., Am. Miner., 44 (1959) 1057.

(37) Lucas S., Champion E., Bregiroux D., Bernache-Assolant D., Audubert F., J. Solid St. Chem., 177 (2004) 1302.

(38) Drozdzynski J., Inorg. Chim. Acta, 32 (1979) L83. 
(39) C.E. Bamberger, R.G. Haire, H.E. Hellwege, G.M. Begun, J. Less Common Metals, 97 (1984) 349.

(40) C.W. Bjorklund, J. Am. Chem. Soc., 79 (1957) 6347.

(41) Cleveland J.M., in : "The chemistry of plutonium", Ed. Gordon \& Breach Science Publishers, New-York, 1970.

(42) Aloy A.S., Kovarskaya E.N., Koltsova T.I., Samoylov S.E., in : "Radioactive Waste Management and Environmental Remediation“, ASME, 2001.

(43) Keller C., Walter K.H., J. Inorg. Nucl. Chem., 27 (1965) 1253.

(44) Rai D., Felmy A.R., Fulton R.W., Radiochim. Acta, 56 (1992) 7.

(45) Weigel F., Hauy H., Radiochim. Acta, 4 (1965) 327.

(46) Hobart D.E., Begun G.M., Haire R.G., Hellwege H.E., J. Raman Spectro., 14 (1983) 59.

(47) Podor R., Cuney M., Am. Miner., 82 (1997) 765.

(48) Podor R., Cuney M., Nguyen-Trung C., Am. Miner., 80 (1995) 1261.

(49) Podor R., François M., Dacheux N., J. Solid State Chem., 172 (2003) 66.

(50) Muto T., Merowitz R., Pommer A.M., Murano T., J. Am. Mineral., 44 (1959) 633.

(51) Feigelson R.S., J. Am. Ceram. Soc., 47, (1964) 257.

(52) Kelly K.L., Beall G.W., Young J.P., Boatner L.A., in : "Scientific Basis for Nuclear Waste Management”, Eds J.G. Moore, New York, Vol. 3, 189, 1981.

(53) Mullica D.F., Sappenfield E.L., Wilson G.A., Lanthanide and Actinide Res., 3 (1989) 51.

(54) Montel J.M., Devidal J.L., EUG XI, Symposium PCM6, Cambridge Publication, 680, 2001. 
(55) Seaborg G.T., in : "Plutonium Chemistry”, Eds. W.T. Carnall \& G.R. Choppin, ACS, Washington, 1983.

(56) Bamberger C.E., Begun G.M., Brynestad J., Land J.F., Radiochim. Acta, 31 (1982) 57.

(57) Dacheux N., Podor R., Brandel V., Genet M., J. Nucl. Mater., 252 (1998) 179.

(58) Pepin G.J., Vance E.R., McCarthy G.J., Mat. Res. Bull., 16 (1981) 627.

(59) Tabuteau A., Pagès M., Livet J., Musikas C., J. Mat. Sc. Let., 7 (1988) 1315.

(60) Heindl R., Flemke E. and Loriers J., Conf. Dig.-Inst. Phys., (1971) 222.

(61) Pepin J.G., Vance E.R., McCarthy G.J., Mater. Res. Bull., 16 (1981) 627.

(62) Imanaka N., Masui T. and Itaya M., Chem. Lett., 32(4) (2003) 400.

(63) Sivakumar V. and Varadaraju U.V., Bull. Mater. Sc., 28(3) (2005) 299.

(64) Shannon R.D., Acta Crystallogr., A32 (1976) 751.

[65] Evain M., « U-Fit program », Institut des Matériaux de Nantes, France, 1992.

[66] Kraus W. and Nolze G., J. Appl. Cryst. 29 (1996) 301.

[67] Abdel-Kader A., Ammar A.A. and Saleh S.I., Thermochim. Acta, 176 (1997) 293.

[68] Montel J.M., Devidal J.L. and Avignant D., Chem. Geol., 191 (2002) 89.

[69] Podor R., Eur. J. Mineral., 7 (1995) 1353.

[70] Dacheux N., Brandel V., Genet M., New J. Chem., 19 (1995) 15.

(71) Montel, J.M.; Glorieux, B.; Seydoux-Guillaume, A.M.; Wirth, R. J. Phys. Chem. Solids 2006, $67,2489-2500$. 
[72] Bénard P., Louër D., Dacheux N., Brandel V., Genet M., Chem. Mater., 6 (1994) 1049.

[73] Dacheux N., Brandel V., Genet M., New J. Chem., 19 (1995) 1029.

[74] Frost R.L., Weier M.L., Martens W. and Cejka J., Vibrational Spectroscopy, 41 (2006) 205.

[75] Frost R.L., Weier M.L., Spectrochim. Acta, A(60) (2004) 2399.

[76] Thomas A.C., Dacheux N., Le Coustumer P., Brandel V. and Genet M., J. Nucl. Mater., 295 (2001) 249 .

[77] McCarthy G.J., White W.B. and Pfoertsch D.E., Mat. Res. Bull., 13 (1978) 1239.

[78] Botto I.L. and Baran E.J., Z. Anorg. Allg. Chem., 430 (1977) 283.

[79] Brandel V., Dacheux N., J. Solid St. Chem., 177 (2004) 4743.

[80] Pascal P., Nouveau Traité de Chimie Minérale, X (1956) Masson, Paris.

[81] Garvie L.A.J. and Busek P.R., J. Phys. Chem. Solids, 60 (1999) 1943.

[82] Colettan M., J. Mater. Sci. Lett., 21 (2002) 1797.

[83] Lide D.R., Handbook of Chemistry and Physics, $73^{\text {rd }}$ edition (1993) CRC Press. 